\title{
O TEMPO, O RITMO E O PENSAMENTO MUSICAL
}

TIME, RHYTHM AND MUSICAL THOUGHT

Carole Gubernikoff Universidade Federal do Estado do Rio de Janeiro - UNIRIO carole.gubernikoff@gmail.com

Maya SuemiLemos Universidade Estadual do Rio de Janeiro - UERJ mayasuemi@gmail.com 


\section{Resumo}

Compositores do início do século XX encontraram meios de transcender a rítmica métrica, em formas de abordar a dimensão temporal da música que reverberam experiências rítmicas anteriores à consolidação da métrica e da harmonia tonal. Percorrendo esses momentos históricos da música, revelam-se maneiras pelas quais se entrelaçam no devir histórico o tempo e o pensamento musical. Exemplos de partituras atestam diferentes esforços de transcender a rítmica e a métrica fraseológica.

Palavras-chave: Tempo, tempo musical, ritmo, métrica, duração

\section{Abstract}

Composers from the beginning of 20th Century found diverse ways to transcend metrical rhythm. These approaches to the temporal dimension of music would recall rhythmic practices from an era before the consolidation of musical meter and tonal harmony. As one goes throughout these moments of music history, different ways in which time and musical thought were intertwined reveal themselves. Musical excerpts from scores reveal different efforts in order to transcend rhythmic and metric phraseology.

Keywords: Time, musical time, rhythm, meter, duration. 


\section{Introdução}

A discussão filosófica sobre o tempo é fundadora do pensamento do qual nós nos consideramos herdeiros. Haver tempo éa própria condição da existência e isto está bem explícito tanto no Timeu, diálogo de Platão, quanto em Aristóteles e Santo Agostinho.

No Timeu, o "mundo" é criado pelo esforço do Demiurgo para curvar e fechar um círculo, circunscrevendo o que seria o de dentro e o de fora. Dentro do círculo, o universo, fora do círculo o sem tempo, o outro, o não mundo. O tempo se processará pelas divisões sucessivas do círculo e pelas direções do movimento. Nesta operação, a proporção, a dimensão, a velocidade e a repetição do movimento são a expressão tanto dos corpos celestes quanto da matéria sonora que, neste caso, se identificam, são o mesmo ou participam do mesmo. Esta dimensão sonoro-corporal é expressa pelos números e pelas proporções fundando a matemática (os números), a geometria (números no espaço), a música (números no tempo) e a astronomia (números no tempo e no espaço).

A discussão do tempo em Aristóteles se encontra em uma outra dimensão, menos metafísica e mais corporal, no volume IV da Física, após a discussão sobre o lugar. Podemos decidir o que contém um lugar, mas não o que um lugar é. Além disso, sabemos que os corpos se transformam e isto indicaria alguma coisa que as faz mudar. Esta "causa" seria o tempo. Entretanto, o tempo não será tratado como causa do movimento nem como efeito do movimento mas como a própria transformação dos corpos. O tempo faz as crianças crescerem, os adultos envelhecerem, as pedras se arredondarem. Porém, para isto sempre haverá uma causalidade corporal: o vento que desgasta a pedra, as enzimas e os hormônios que fazem crescer, o desgaste dos órgãos que faz envelhecer. Estes efeitos se darão sempre pela ação de outros corpos, mas o tempo não tem um corpo e não podemos dizer que ele seja a causa e a finalidade metafísica dos movimentos e das transformações.

Nas Confissões de Santo Agostinho, a discussão do tempo se inicia pela ruptura entre um reino da eternidade e a dimensão temporal, onde estamos imersos. Ela passa das questões materiais, físicas e metafísicas para temas relacionados com a percepção do tempo, para finalmente descrevê-lo como o canto de um salmo, em que simultaneamente se louva a Deus e adquire-se a consciência, através da enunciação de cada sílaba, de que algumas se passaram e outras ainda virão. O canto torna-se, assim, a consciência do tempo, mas não a reposta sobre a sua essência.

Se seguirmos as tautologias indicadas pelas versões de Platão, em que a música é uma medida do tempo, e a de Santo Agostinho onde, quando cantamos, vivenciamos o que seja o tempo, estamos identificando o tempo com a música. Elas instauram uma série de paradoxos que vão perdurar até que a música se separe do tempo, afirmada pelo seu elemento sonoro e não pela sucessão de pontos numéricos abstratos, pela sucessão dos instantes. Kant, na Crítica da Razão Pura, no capítulo denominado Estética transcendental, efetivou o que Deleuze chamou de Revolução Copernicana da filosofia. Pois, nele, tempo e espaço são a priori que se encontram no sujeito. São eles que possibilitam o conhecimento, e projetam sobre o mundo os esquemas do entendimento. 


\section{O devir do tempo musical'}

O tempo musical, da mesma maneira que o conceito filosófico de tempo, não pode ser definido pelo que ele é, mas pelo seu devir, pelo que foi e o que vem a ser.

Embora a música tenha sido, desde a Antiguidade, vinculada a noções temporais de duração e proporção, a sistematização do tempo musical - sua notação e sua teorização, para além da práxis - teve início no Ocidente somente a partir do século XII, impulsionada pela tendência ao enriquecimento do canto polifônico eclesiástico e o que isto significava em termos de necessidade de controle das durações. Pois, quando no canto litúrgico começou-se a superpor mais de duas ou três linhas melódicas, o controle estrito da duração dos sons passou naturalmente a ser uma condição para o controle, também, das consonâncias. O que hoje para nós parece banal e natural - a possibilidade de uma divisão regular do tempo musical em proporções de 2 ou 3 tempos e a representação gráfica por meio de signos de valor temporal que conhecemos hoje - levou séculos para se constituir, se naturalizar e se estabilizar, num processo de construção complexo, que podemos situar, grosso modo, entre os séculos XII e XVII. A menção, aqui, a um processo e uma construção não significa a adesão a uma perspectiva teleológica sobre a consciência do tempo musical. Cada uma das formas de organizar o parâmetro temporal da música, que se sucederam ao longo dos séculos, possuía uma lógica própria e original, indissociável da práxis, do repertório e do pensamento musical de seu tempo, com os quais compunha um sistema coeso. Prova disto é a inevitável imperfeição da transcrição de um repertório antigo para a notação moderna, ou vice-versa. Se o modelo notacional de Franco de Colônia, por exemplo, vigente no século XIII, não se mostraria eficiente para a representação de composições de nosso século por diversas razões, dentre elas a simples inexistência da mensuração binária, tampouco o sistema moderno se presta bem a notar a complexidade da estrutura rítmica do repertório da Ars nova, por exemplo, ou as inflexões rítmico-melódicas do cantochão. Em qualquer sentido desta operação, transcrições são traduções, como jábem mostrou a musicologia, ou, emoutras palavras, deslocamentos entrelinguagens distintas. Não se trata, assim, de tomar a sucessão histórica de sistemas de organização do tempo musical como o processo de aperfeiçoamento de um modelo fadado a prosperar e se impor, mas efetivamente como um devir, como um movimento.

A música medieval que nos foi transmitida por meio de notação é quase essencialmente vocal e, assim, intrinsecamente vinculada à poesia ${ }^{2}$. Seus parâmetros temporais são, consequentemente, relacionados de forma estreita aos parâmetros temporais da construção poética. A métrica da poesia grega, que foi transmitida à poesialatina antiga e continuou a ser ensinada nas escolas monásticas, era organizada segundo a nature-

\footnotetext{
1 Agradecemos a Pedro Hasselmann Novaes pela leitura minuciosa desta seção, pelas contribuições e precisões referentes ao repertório e à notação medievais. Os eventuais erros ou imprecisões são, naturalmente, da exclusiva responsabilidade das autoras.

2 Embora os relatos literários indiquem uma presença intensa da música instrumental na vida cotidiana, a quantidade de registros notacionais remanescentes de música instrumental é residual, se comparada à de música vocal. São exemplos de música instrumental grafada as variações e diminuições do Codex Faenza e do Buxheimer Orgelbuch, que partem de modelos vocais, ou as estampidas italianas e as do Codex de Robertsbridge, cujo caráter idiomático e improvisatório dá a entender uma independência do canto.
} 
za e do número de pés métricos - células formadas por sílabas longas e breves que constituíam padrões temporais - aos quais se superpunham acentos de acuidade (ictus) indicativos de uma leve elevação vocal. Ainda nos primeiros séculos da nossa era, no entanto, o latim foi sofrendo modificações. A distinção quantitativa entre sílabas longas e breves foi se perdendo e sendo substituída pela distinção qualitativa entre sílabas tônicas e átonas (SCHMITT, 2016 , p. 67 et. seq). De maneira que a poesia, já na Alta Idade Média, não é mais métrica, mas rítmica. Ela é organizada em versos ritmados por uma sucessão regular de sílabas acentuadas e não acentuadas, típica da versificação moderna ${ }^{3}$. Rhythmus, aliás, designa entãojustamente esta forma de versificação característica da poesia cantada. Em outras palavras, o ritmo, aí, pode ser definido como a organização de sons que configuram gestalts através da escansão que imprimem ao canto. Beda o Venerável definiu assim, em torno de 710 d.C, a distinção entre as poesias rítmica e métrica4:

O verso rítmico se assemelha ao verso métrico. O verso rítmico é um arranjo harmonioso de palavras escandidas não por um sistema quantitativo de metro, mas pelo número de sílabas definido pela maneira que soam ao ouvido, assim como são os versos dos poetas comuns. O ritmo pode certamente existir por si só, sem o metro, mas o metro não pode existir sem ritmo. Isso pode ser definido mais claramente da seguinte maneira: o verso métrico é um sistema quantitativo com batimento rítmico, enquanto o verso rítmico possui uma batida rítmica sem um sistema quantitativo. No entanto, podem-se encontrar quantidades no verso rítmico ao acaso, não porque a arte da medida tenha sido preservada, mas por influência do som e do batimento rítmico em si. Os poetas populares fazem de maneira não advertida o que os poetas eruditos fazem de maneira sabedora. (BEDA, 2015, s/n)

Beda retoma e desenvolve aí uma célebre fórmula do De Musica (c. 391), de Santo Agostinho, retomada por vários autores ao longo dos séculos: "Todo metro é um ritmo, mas nem todo ritmo é um metro". Para Agostinho, o ritmo é uma sucessão de batimentos regulares sem limite definido, diferentemente do metro, constituído por um número determinado de batimentos regulares, os pés (AGOSTINHO, 2009, p.163).

A medida da resiliência da métrica antiga na cultura medieval e, sobretudo, o grau de sua influência no advento da notação do parâmetro temporal na música é objeto de controvérsia entre os estudiosos. É contudo a partir de células padrão compostas de sons breves e longos - com ou sem razão identificadas a posteriori aos pés métricos gregos - que se constituirá a primeira experiência notacional de controle do tempo musical no Ocidente: a chamada notação modal, materializada num repertório da escola de Notre-Dame situado entre fins do século XII e as primeiras décadas do século XIII , e codificada nos textos teóricos de Jean de Garlande 5 .

\footnotetext{
3 Embora o acento naquele momento não fosse mais um acento de elevação de frequência, como na poesia clássica, mas sim um acento de intensidade, ou intencionalidade. Cabe lembrar que o termo accentus deriva da expressão ad cantus, ou seja, aquilo que deve ser cantado (SCH- MITT, 2016, p. 75).
} rítmico. 
Ébem verdade que a notação neumática, surgida séculos antes da notação modal, comportava expedientes indicativos da temporalidade do canto: o formato de determinados neumas, a aposição da episema marcando um alongamento da duração, o uso de letras do alfabeto indicativas de velocidade, ou ainda o recurso à espacialização dos neumas são alguns exemplos. No entanto, tratava-se de um controle relativo, uma vez que não estabelecia, como o fez a notação modal, uma pulsação e uma contagem (de breves e longas com valores proporcionados entre si) como parâmetros obrigatórios de controle temporal.

Num contexto de influxo da aritmética nos diversos campos da existência (MURRAY, 2002), dos mais práticos aos mais simbólicos - da medida do tempo à contagem do tempo do purgatório, passando pelos pesos e medidas, pela astronomia - emerge um sistema que permite determinar a duração proporcional dos sons musicais a partir de seis modos rítmicos: LB ( $1^{\circ}$ modo); BL ( $2^{\circ}$ modo); LBB ( $3^{\circ}$ modo); BBL ( $4^{\circ}$ modo); LL ( $5^{\circ}$ modo); BBB ( $6^{\circ}$ modo). Uma nota será longa ou breve em função de sua inserção num dos modos ${ }^{6}$. Se a poesia rítmica já há muito provia o canto de uma escansão regular, de uma pulsação, o que emerge aqui é uma definição estrita da relação proporcional de duração entre breves e longas: via de regra, uma breve dura um tempo e uma longa, três tempos ${ }^{7}$. Este passo fundamental, que significa o controle simultâneo do tempo e das consonâncias entre as vozes, permite uma superposição ad libitum de linhas melódicas, inclusive de linhas melódicas compostas em modos rítmicos distintos. A banalidade da lógica do sistema é apenas aparente. Ele resulta de um processo notável de abstração e racionalização de uma temporalidade até então essencialmente prática, vivenciada na realidade e na materialidade imediata do texto poético e suas qualidades rítmicas. Perfeitamente condizente com a racionalidade escolástica então em seu pleno vigor, a intelectualização do tempo musical, que tem na notação modal sua primeira materialização visível, atravessa os sistemas notacionais subsequentes num crescendo do domínio, da capacidade de manipulaçãoe exploração criativa da dimensão temporal do som, de suas possibilidades rítmicas.

\footnotetext{
6 Na notação modal, o reconhecimento da duração breve ou longa de uma nota não se dá por seu formato, mas por seu contexto dentro de um dos modos. 0 reconhecimento do modo, por sua vez, se faz pela maneira pela qual as notas se distribuem na linha melódica da partitura, em configurações (ligaduras) de duas, três ou quatro notas. Assim, por exemplo, uma linha melódica que se apresente como uma sequência formada por uma ligadura tripla (formada por três notas) seguida de ligaduras duplas (formadas por duas notas) indica que se trata do $1^{\circ}$ modo. Uma sequência de ligaduras duplas seguida de uma ligadura tripla indica o $2^{\circ}$ modo etc. Uma vez reconhecido o modo da melodia, encontram-se definidas as durações das notas. Para uma visão detalhada da notação, remetemos a APEL, Willi. The Notation of Polyphonic Music, 900-1600. Cambridge, Massachusetts: The Mediaeval Academy of America, 1942; PARRISH, Carl. The Notation of Medieval Music. New York: Pendragon Press, 1978 [1957].
}

7 Anotação modal ea notação franconiana que a sucede concernem uma mensuração ternária (com exceção da divisão da B na notação modal, que em geral resulta em grupos de duas ou quatro semibreves). A isto se deve a ambiguidade no valor temporal das $B$ e $L$. As células devem sempre somar três tempos ou múltiplos de três. Assim, em células de tipo LB (típica do $1^{\circ}$ modo) e BL (típica do $2^{\circ}$ modo), a L vale 2 tempos (longa imperfeita), e a B, 1 tempo (breve recta, ou regular), somando 3 tempos. Em células de tipo LBB (típica do $3^{\circ}$ modo) e BBL (típica do $4^{\circ}$ modo), a L vale 3 tempos (Ionga perfeita), a primeira B vale 1 tempo (breve recta) e a segunda breve vale 2 tempos (breve alterada), de maneira a completar 3 tempos com a B que lhe antecede. 


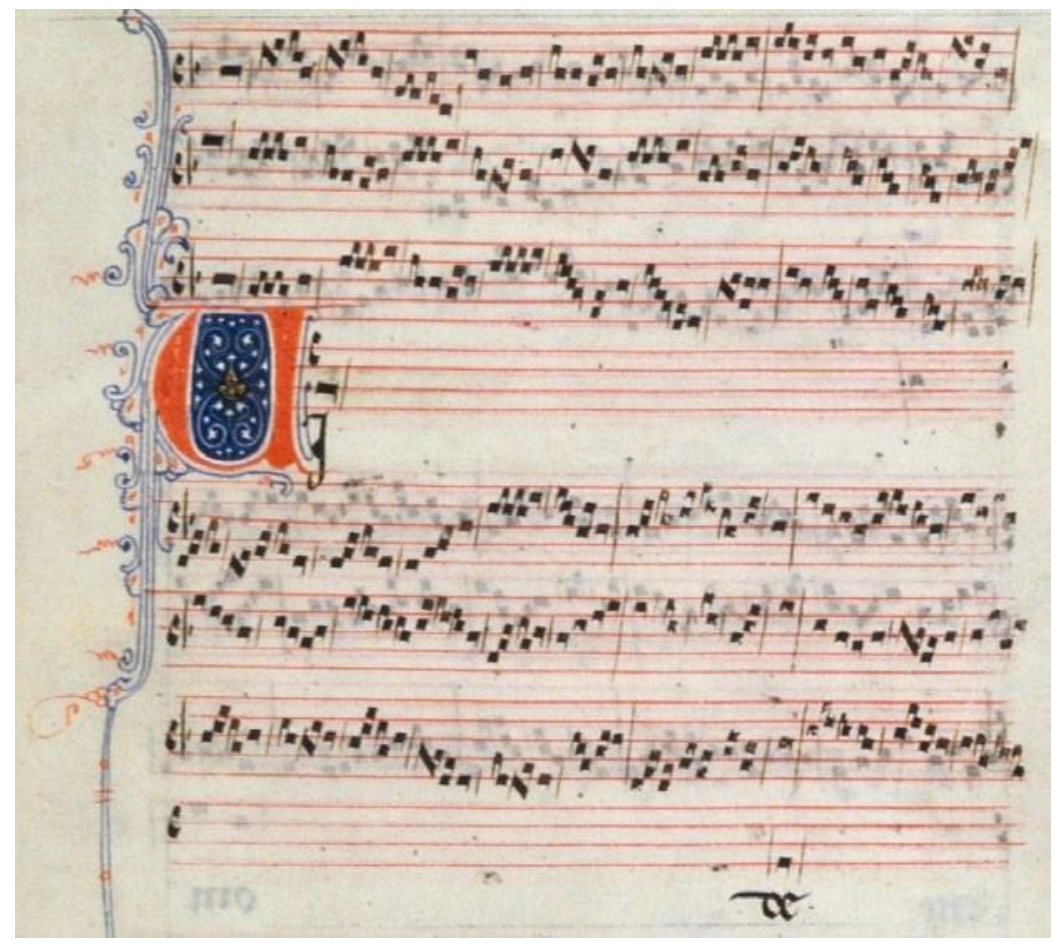

Fig. 1. Notação modal, séc. XIII. Perotino, organuma quatro vozes Viderunt Omnes. Biblioteca MediceaLaurenziana, Florença, MS Pluteus 29, codex 1, ff 1-4.

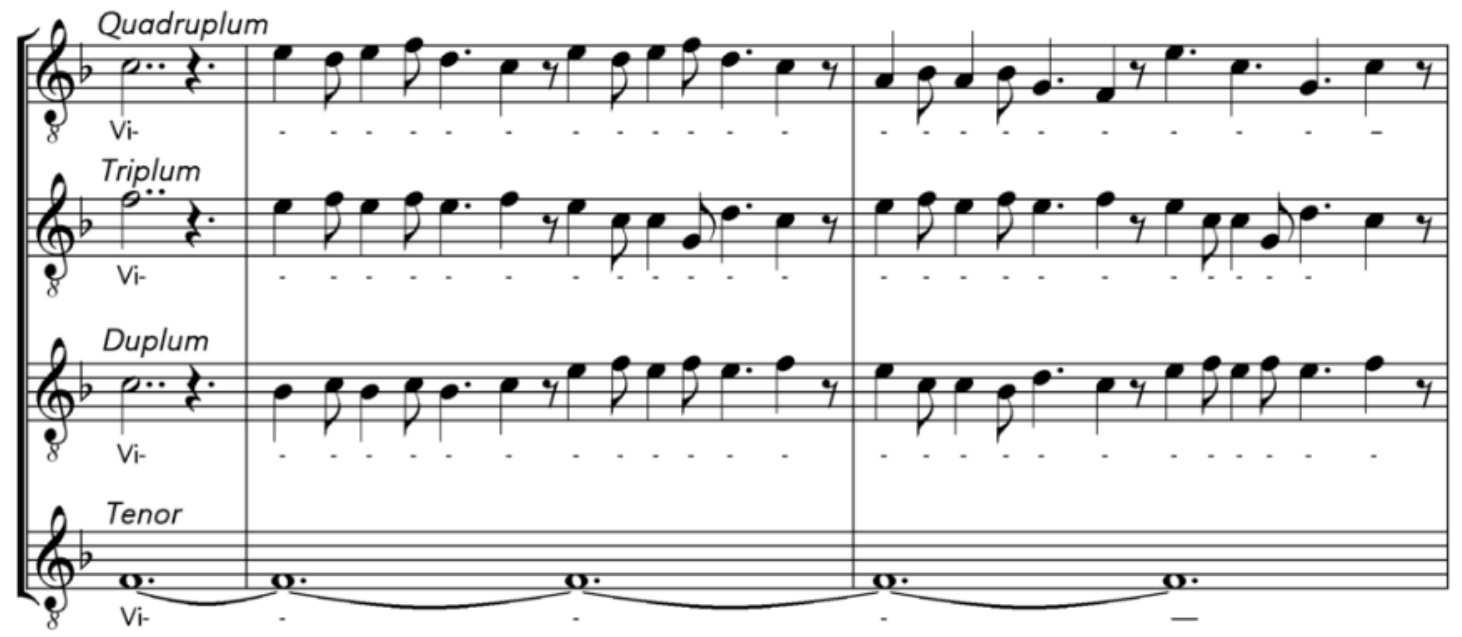

Fig. 2. Transcrição moderna do início do organum a quatro vozes Viderunt Omnes, Perotino. As três vozes superiores estão no primeiro modo, LB.

Com o sistema de Franco de Colônia ${ }^{8}$, a mensuração das longas, breves e semibreves adquire independência do esquema dos modos, pois o formato das notas e das ligaduras passa a indicar sua duração intrínseca. Os signos notacionais em uso até então (oriundos na escrita neumática e grafados de forma quadrada na notação modal) são mantidos, mas investidos de valores intrínsecos. Por exemplo, o punctum passa a representar necessariamente o valor de breve (um ou dois tempos, como na notação modal) e a virga, o valor de longa (dois ou três tempos, como na notação modal); as 
ligaduras de notas são agora distintas entre ligaduras-padrão (cum proprietate et cum perfectione) e variantes (com ou sem propriedade; com ou sem perfeição), o que permite designar de maneira fixa o valor de cada uma de suas notas (se é uma longa, breve ou semibreve). Mas, sobretudo, na medida em que passa de uma lógica aditiva (de acúmulo de células métricas, da notação modal) para uma lógica de subdivisão proporcional $^{9}$, o sistema franconiano estabelece as bases da notação em vigor até o séc. XVI, e em alguns aspectos, da notação moderna. Seu resultado prático é a possibilidade de uma variação rítmica - sempre ternária, é preciso lembrar - agora independente do esquema rígido e pouco variável dos modos rítmicos. Nas últimas décadas do século XIII, Pierre de la Croix, ou Petrus de Cruce, fez inovações rítmicas na notação do triplo (voz superior) de seus motetos: por meio do uso do ponto de divisão (punctus divisionis), as breves podiam ser divididas, e sem dificuldade de leitura, em grupos não apenas de duas ou três, mas também em grupos de quatro, cinco, seis e até mesmo sete semibreves. Isto permitiu não apenas uma movimentação silábica ágil da voz aguda, de destacado caráter declamatório, mas também uma notável flexibilidade rítmica, numa vertente que será levada adiante pela notação italiana do século seguinte. Em motetos de Pierre de la Croix, a agilidade e flexibilidade declamatória do triplum se superpõe à progressão mais melodiosa do moteto (duplum), e em contraste com a movimentação sempre mais econômica do tenor. Embora a exploração das características distintas das partes vocais, incluindo as possibilidades declamatórias na melodia do triplum, sejam típicas do moteto do século XIII, Pierre de la Croix, por meio de sua notação do triplum, eleva esta variedade de rítmicas concomitantes a um novo patamar ${ }^{10}$.

\footnotetext{
9 Uma duplexé dividida em duas longas; uma longaé dividida em três breves rectas (deum tempo) ou duas breves desiguais (uma recta de um tempo e uma altera de dois tempos, formando sempre uma perfectione, um agrupamento de três tempos); uma breve é dividida em três semibreves minores (valor de 1/3 da breve) ou duas semibreves desiguais (uma minor de 1/3 e uma major de 2/3).
}

10 Assinalamos aqui a valiosa contribuição de Pedro Hasselmann Novaes no que tange ao estilo musical dos motetos de Pierre de la Croix. 


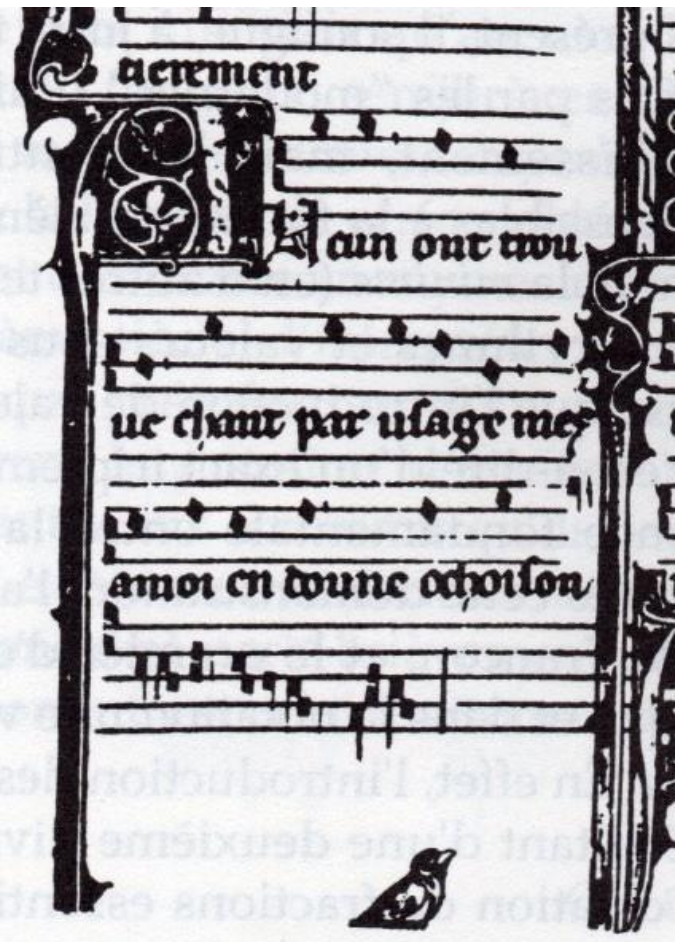

Fig. 3. Pontos de divisão no início da voz superior (trip/um) do moteto Aucun ont trouvé chant / Lonc tans me sui tenu / Annuntiantes, de Petrus de Cruce, séc. XIII.
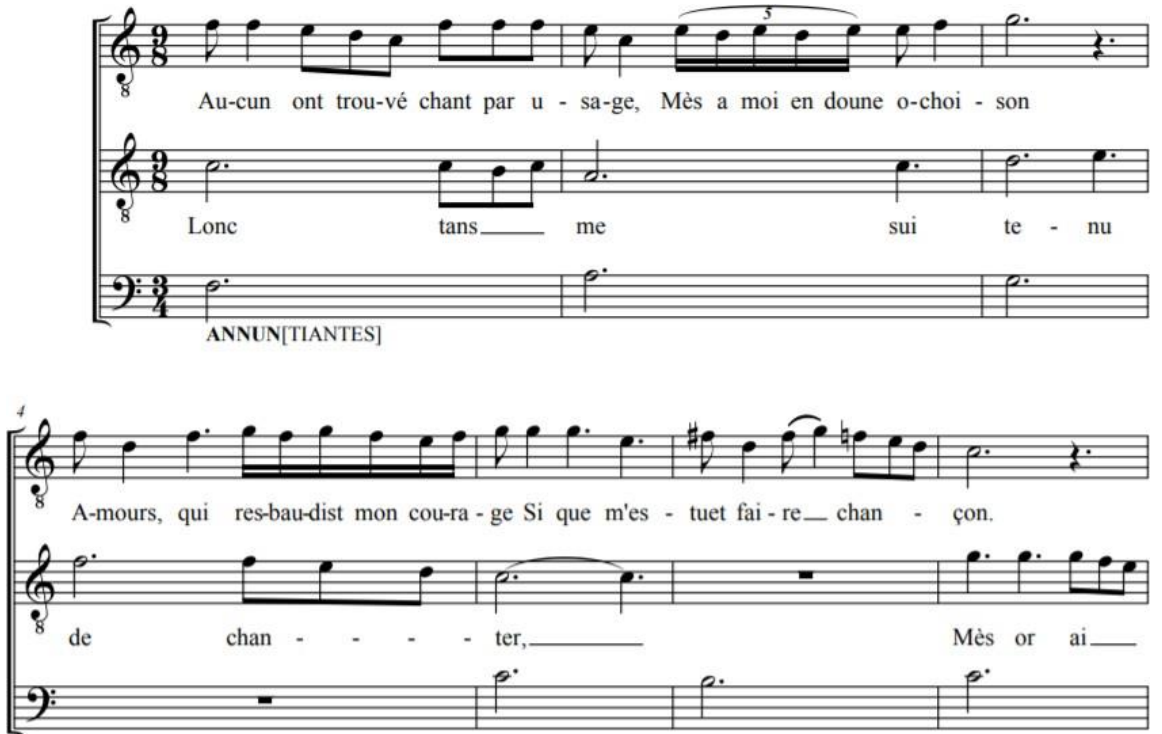

Fig. 4. Agrupamentos de 3, 5 e 6 notas (semibreves no original). Início do moteto Aucun ont trouvé chant / Lonc tans me sui tenu / Annuntiantes, Petrus de Cruce ${ }^{11}$. Transcrição moderna por Leonardo Wonsik.

Com o sistema notacional da Ars nova sistematiza-se a divisão proporcional também da semibreve (em semibreves mínimas), numa tendência à aceleração rítmica, mas, sobretudo, formaliza-se o uso da mensuração binária, por meio do sistema de prola- 
ções: a noção de perfeição e imperfeição (divisão, respectivamente, em três e dois) afeta agora todos os níveis de divisão, e proporções binárias e ternárias podem se combinar livremente entre os distintos níveis. Pormeio desta notação, teorizada nas primeiras décadas do século XIV por Johannes de Muris e Philippe de Vitry, materializa-se um repertório de motetos cuja arquitetura rítmica atingiu patamares extremos de elaboração, complexidade e refinamento, da qual o moteto isorrítmico é um exemplo cabal.

A intelectualização do tempo musical chega ao seu paroxismo com o virtuosismo aritmético da notação proporcional do século XV. Lançando mão de uma extensa variedade de signos e frações, ela permitiu jogos de relações proporcionais de tempo altamente complexos, quase inextrincáveis, no limite da viabilidade prática, ou mesmo bem além dele. Se a intenção efetivamente musical desses exercícios de abstração matemática é muitas vezes posta em dúvida, não se pode deixar de enxerga-los como exemplos fulgurantes do termo de um processo que, atravessando diversas experiências notacionais, culminou, ao cabo de alguns séculos, na completa apropriação de um tempo musical agora manejado e explorado criativamente com extraordinária maestria.

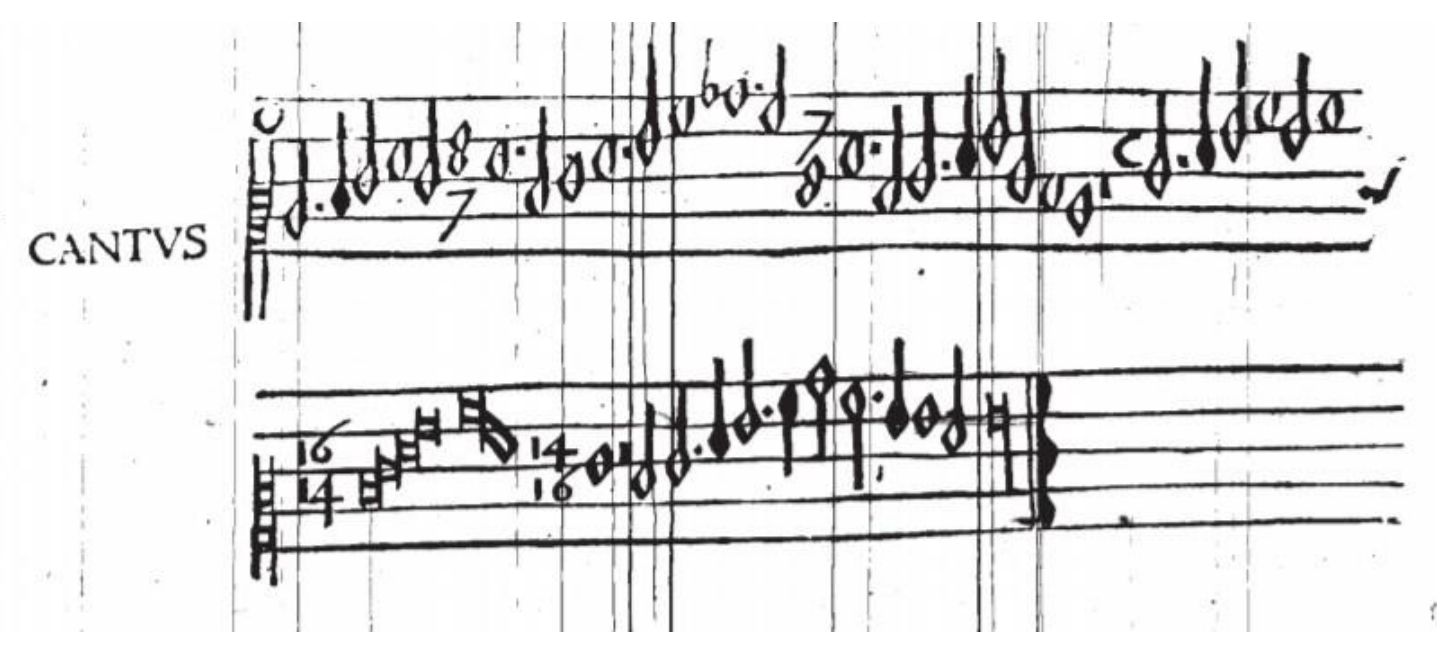

Fig. 5. Signos mensurais e proporções em Franchinus Gaffurius, Practica musicae, 1496, De proportione sesquiseptima.

Os ventos parecem porém soprar diferentemente a partir daí, conduzindo as preocupações musicais para outros caminhos, como testemunham as inúmeras invectivas dirigidas ao sofisticado e virtuosístico sistema de proporções. O compositor e teórico Adrian Petit Coclico recomendará aos jovens músicos, no seu tratado de 1552, a "não desperdiçarem seu tempo com os extensos textos dos matemáticos da música que inventaram tantas categorias de sinais de aumento e diminuição, dos que não deriva prazer, mas discórdia e querelas em quantidade, e pelas quais uma coisa em si clara se torna obscura" (COCLICO, 1552, s/n). Denotando claramente o influxo humanista e as preocupações novas, de ordem expressiva, que dele decorrem, Coclico afirma que: "Na verdade, o músico é aquele que, em vez de tagarelar e rabiscar montes de números e proporções, sinais e valores de notas, sabe cantar com bom gosto e graça, dando a cada 
nota a sílaba apropriada, e compor de maneira colocar palavras alegres em tons alegres e vice-versa (...)" (COCLICO, 1552, s/n, nossa tradução) $)^{12}$.

Visivelmente, o impulso de intelectualização e de abstração saía da ordem do dia, dando lugar à simplificação que caracterizou a notação nos séculos seguintes. Em suas Istitutioni Harmoniche (Veneza, 1558), Gioseffo Zarlino, o mais eminente teórico da música do século XVI se referirá ao complexo sistema de proporções como "coisa de geômetra”, e não de músico (ZARLINO, 1558, p. 279), e aos signos proporcionais como elementos complicadores alheios à natureza sensível da música.

Edisto dão fé muito livros compostos por diversos autores que não tratam senão de círculos e semicírculos, pontuados e não pontuados, inteiros e cortados não somente uma vez, mas também duas, nos quais se vê tantos pontos, tantas pausas, tantas cores, tantas cifras, tantos sinais, tantos números contra números, e tantas outras coisas estranhas que parecem às vezes livros de um mercador abstruso. Nada mais se lê nesses seus livros que possa conduzir o homem à compreensão de algo, que remeta ao juízo da audição, como são as vozes, ou os sons dos quais nasce as harmonias e as melodias" (ZARLINO, 1558, p. 279, nossa tradução).

Considerações como as de Zarlino e de Coclico, algumas apenas entre muitas vozesuníssonas, indicam que os recursos temporais serão solicitados doravante não mais para a construção de arquiteturas rítmicas intelectualizadas que, em larga medida, extrapolavam em importância a dimensão do texto poético, mas sim para mimetizar e realçar as inflexões desse mesmo texto poético, de mais em mais assumido como elemento fulcral da composição musical. Supérfluos no contexto do novo programa, os rebuscamentos notacionais saem de cena. Nela permanece um repertório de figuras de tempo suficientemente vasto, capaz de seajustar às inflexões da declamação do texto e a representar seus conteúdos, e um sistema métrico capaz de oferecer enquadramentos variados para sua estruturafraseológica. Poderíamos dizer que, do ponto de vista do tempo, o alvo estético se desloca via de regra da contemplação de uma estrutura arquitetônico-temporal bela per se, para a experiência de imersão num fluxo direcional cuja estrutura de base fraseológica implica na gestão de expectativas, similar à perspectiva nas artes visuais. Nãoé uma coincidência, neste sentido, que a consolidação da métrica, da dimensão espaço-temporal parametrizada se dê pari passu com a consolidação da tonalidade harmônica: métrica e sistema tonal são inseparáveis numa música que, por séculos a seguir, se traduzirá na gestão da expectativa auditiva.

É dentro desta perspectiva que estudamos na análise musical a segmentação métrica e suas relações com a forma, associando à métrica as relações harmônicas que produzem direcionalidade. Neste contexto, a tonalidade ou o tom principal funciona como o ponto de vista para onde se dirigem, linearmente, as configurações rítmicas e os padrões métricos sob a forma de frases, períodos, seções, partes, andamentos, movimentos, obras. Estas são as bases dos fundamentos da disciplina a que chamamos análise musical. Nela, a temporalidade se associa à fraseologia, às segmentações em seções e partes até à configuração final de um movimento ou de uma peça. As pequenas configu- 
rações rítmicas estariam ligadas aos gestos ou à criação de padrões rítmicos que podem ser baseados nos acentos da fala poética, na retórica e seu fraseado, a partir de delimitações de campos temporais menos rigorosos, ou ainda dos movimentos corporais.

\section{O ritmo reemergente}

No final do séculoXIX, após a reintrodução na escrita notacional de ritmos oriundos das tradições populares e suas transformações criadas pela própria notação, a questão do ritmo explode, principalmente nas criações de compositores como Claude Debussy, Igor Stravinsky, e também nos compositores de caráter neoclássico nas Américas: Heitor Villa-Lobos, Carlos Chaves, Silvestre Revueltas, George Gershwin, Aaron Copland, e inúmeros outros que trilharam o caminho da exploração de ritmos afro-ameríndios.

Em sua descrição dos ritmos gregos antigos, Maurice Emmanuel já havia observado que eles dependiam de movimentos corporais que evitavam a regularidade da simetria dos corpos de maneira aditiva, a partir do menor valor, e não proporcional, a partir de divisões (EMMANUEL, 1911 ). Estas importantes informações começam a circular nos meios musicais no início do século XX e podem ser percebidas tanto como um sintoma quanto como uma orientação que vai mudar, ou pelo menos, impactar a métrica e a rítmica. Podemos ver então que o estudo do ritmo envolveria a partir daí ao menos três questões importantes que se tornam, em seu devir, a temporalidade musical: o acento das palavras, as movimentações corporais e a respiração.

Os compositores neoclássicos, que desenvolveram escritas fortemente marcadas pelas tradições populares, não desenvolveram uma reflexão mais profunda sobre a temporalidade musical. Assim, é em Claude Debussy e a seguir, em Igor Stravinsky, Arnold Schoenberg e Anton Webern, que a temporalidade aparecerá como questão em relação à forma musical.

A preocupação com a temporalidade musical em Debussy pode ser observada na maneira com que constrói algumas de suas obras por camadas. Desde 1962 este aspecto já havia sido ressaltado pelo compositor Jean Barraqué, estudioso de seu processo composicional. Um trecho da conclusão de seu livro sobre Debussy serve para ilustrar a importância que este aspecto ganhou para os compositores da segunda metade do século XX:

Com Debussy a obra inventa seu próprio destino e assim chega a uma pré-figuração do tempo musical. (...) Em Debussy a forma não pode mais ser compreendida como uma sucessão ou uma aquisição progressiva por encadeamento de ideias, mas como uma proliferação de instantes determinantes que permitem todos os amálgamas, as elipses, a oposição de forças motrizes. (BARRAQUÉ, 1994, p. 231-232, nossa tradução)

Um dos exemplos mais notório é o do prelúdio Voiles. Na figura 6a, é apresentada uma ideia hexatônica descendente, num ritmo liquescente (a), em seguida uma nota pedal, que se transformará numa nota som, ou sonoridade fixa (b), depois uma terceira ideia mais lenta, em forma de $\operatorname{arco}($ (c). Estes gestos, que Didier Guigue apropriadamente 
chamou de objetos musicais, além de se caracterizarem por um timbre, uma cor, uma densidade, estão articulados entre si em diferentes temporalidades: uma mais rápida (a), uma fixa (b) e outra muito lenta e estendida (c). Como não há um centro tonal (todas utilizam a escala de tons inteiros), não se dirigem a uma tônica e podem se sobrepor em diferentes combinações: abc, cba, acb.
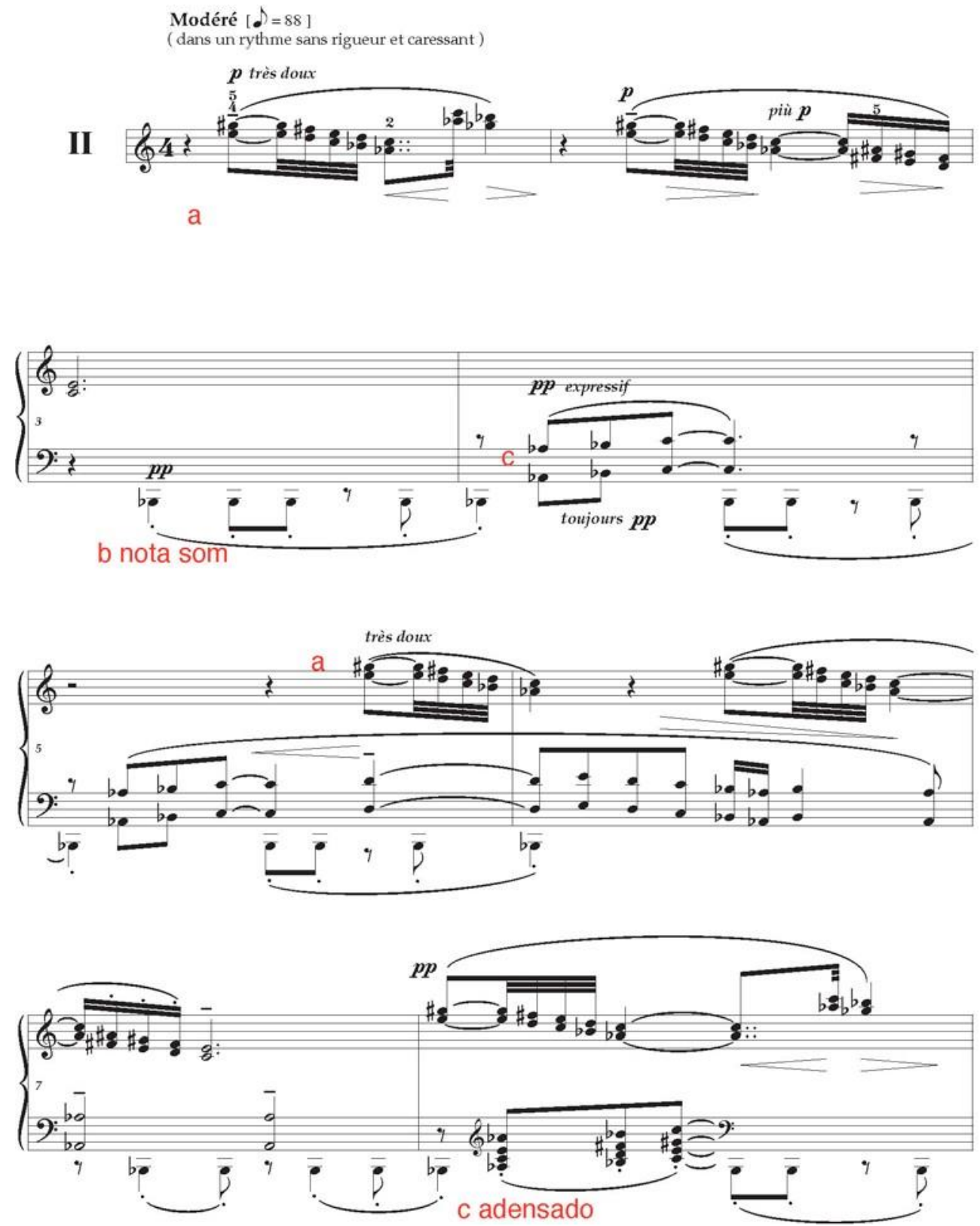

Fig. 6a. Três enunciados, a, b, e c Claude Debussy, Voiles. Piano Practical Editions, 2018. 

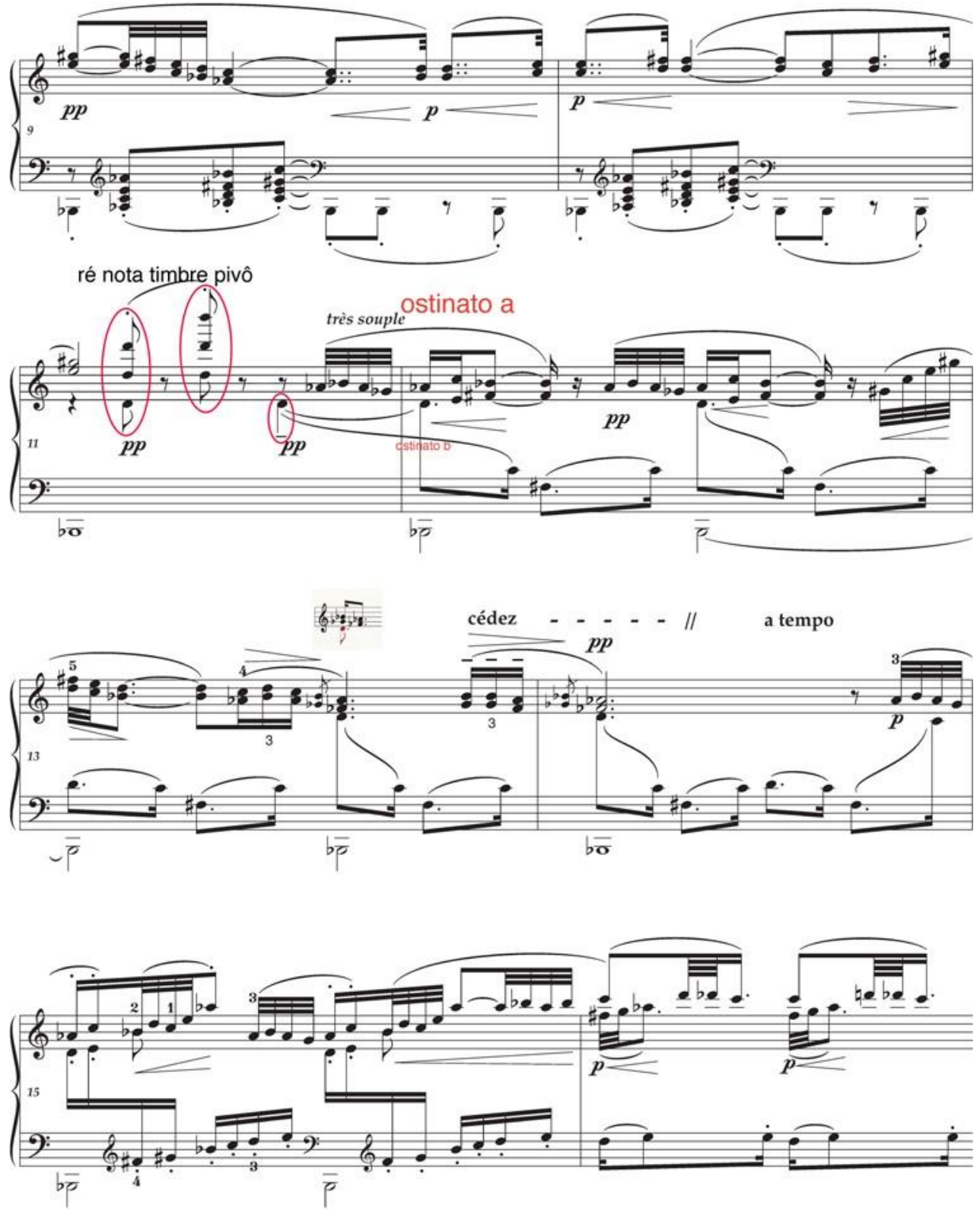

Fig. 6b. A nova nota som, ré, dois ostinatos em: Claude Debussy, Voiles. Piano Practical Editions, 2018.

Esta primeira seção se dirige a uma suspensão temporal, para se fixar em torno da nota ré. Novas camadas temporais, desta vez estabelecidas por células repetidas, ostinatos em torno da nova nota fixa ré, que ressoa em diferentes oitavas. Esta fixação não produz centro tonal, mas estatismo e suspensão temporal. Estes procedimentos de fixação de objetos rítmicos sonoros que se relacionam de modo livre, sem direcionalidade, estão bem expressos quando o compositor se autodenominava "ritmista colorista". Estas camadas sobrepostas de ostinatos conduzem a uma nova configuração da nota fixa ré.

$\mathrm{Na}$ Sinfonia para instrumentos de sopro, composta em homenagem a Debussy por ocasião de sua morte, Stravinsky demonstra como foi importante sua herança no controle da temporalidade musical. Logo no início há uma sequência de eventos de extensão 
e pulsação variados e fragmentários. O primeiro, uma espécie de melodia acompanhada septenária, subentende uma velocidade de colcheias, o segundo, dois tuttiestáticos e suspensos que subentendem uma velocidade de semicolcheias, e o terceiro, blocos homofônicos de semínimas. Estes blocos serão reapresentados em ordens diferentes durante a exposição. A passagem para a seção seguinte traz indicada a mudança de referência métrica, numa disposição que antecipa as modulações métricas de Eliot Carter.

Uma partitura surpreendente é Piano RagMusic, de Stravinsky, composta em 1919. Em várias ocasiões ele comentou que não se interessava pelo jazz, mas que se interessava pelo desafio de ver como era escrito. Nesta obra, encontramos longos trechos sem definição de compassos, que poderíamos interpretar como uma escrita puramente rítmica, que segue as configurações sobrepostas que estabelecem a velocidade e as medidas através dos ostinatos e das repetições. Estas longas seções livres são alternadas com seções de métricas variadas, evitando-se a repetição das fórmulas. Este exemplo demonstra a enorme dificuldade de reproduzir a liberdade temporal da performance, uma vez que a notação não reproduz, mas cria novas possibilidades rítmicas. Na figura 7, reproduzimos uma página da partitura de Piano Rag Music. Stravinsky procura a complexidade das figuras rítmicas jazzísticas. Após muitas mudanças de compasso, parece desistir e apenas esboçar figuras rítmicas, sem as barras métricas.
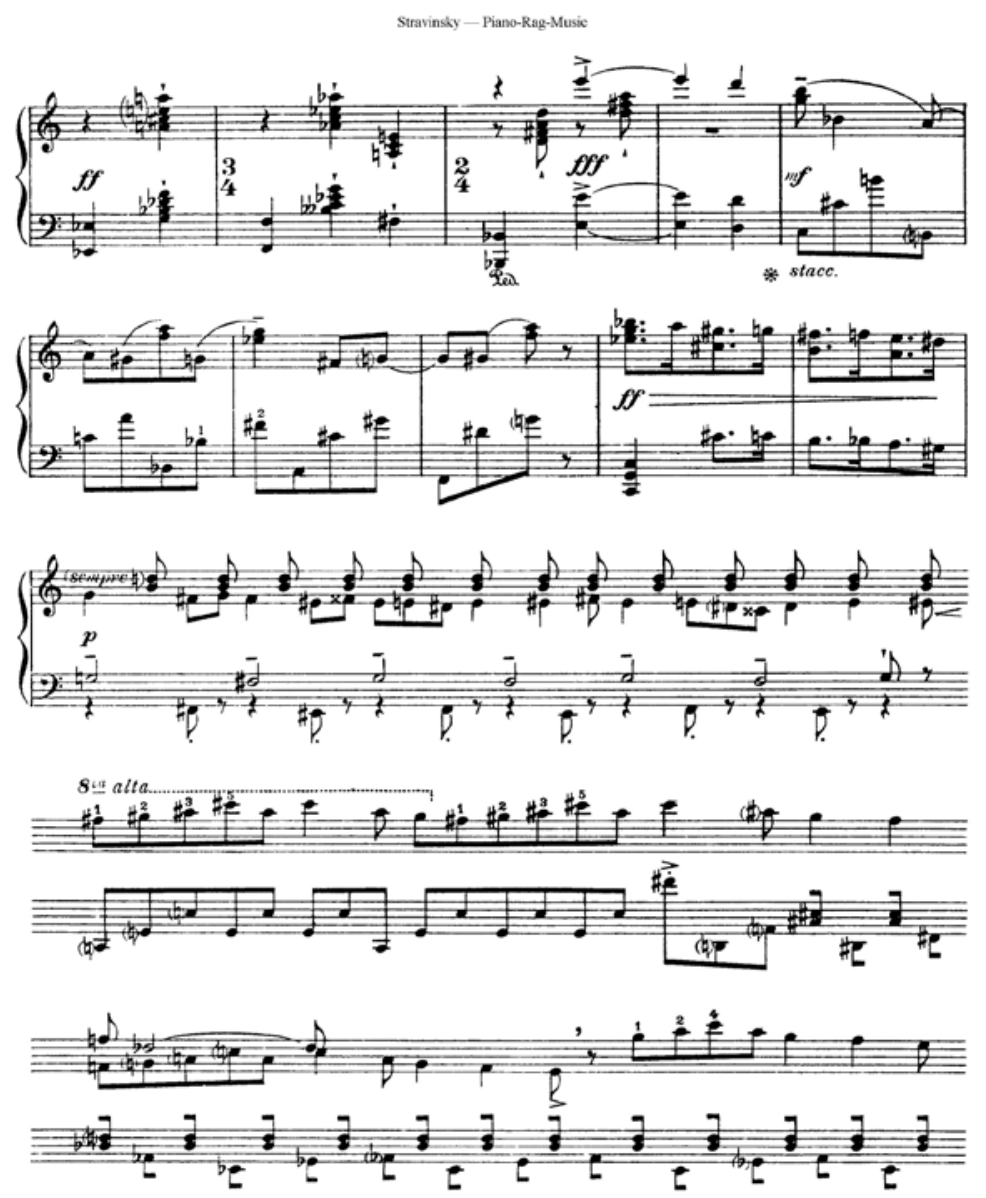

Fig. 7. Configurações rítmicas in Igor Stravinsky. Piano Rag Music. London, J. \& W. Chester [1920]. 
Olivier Messiaen segue naturalmente as preocupações rítmicas e métricas da composição musical do século XX, com fortes referências a Debussy e Stravinsky. Seu sistema se baseou não apenas nas composições de seus contemporâneos, mas também nas "lições" extraídas das aulas no Conservatório de Paris: Maurice Emmanuel e a lógica aditiva grega, o canto gregoriano e a rítmica baseada na prosódia e livre da métrica, os ritmos hindus e a natureza.

Cabem aqui algumas considerações que retomam o problema filosófico do tempo, mas a partir de Hegel. Seguindo a "revolução copernicana" de Kant, para Hegel o tempo se localiza no sujeito e é, juntamente com o espaço, um dos a priori do conhecimento. Entretanto, Hegel introduz um terceiro elemento: o sujeito se apresenta como a mediação e a medida entre o espírito e a natureza. Dentro desta perspectiva, a natureza seria livre e sempre não medida, e caberia ao sujeito projetar a regularidade e estabelecer a base abstrata para a medida do tempo. Esta profunda identidade entre o tempo do sujeito e o tempo da música transformam a música na mais subjetiva das artes. Poderíamos descrever a relação entre a música, o sujeito e o espírito em Hegel da seguinte maneira:

O eu, que percebe e deve perceber nos sons um eco de sua interioridade, deve
se objetivar na música para se tornar consciência. Ele não pode permanecer in-
determinado, mas deve se concentrar sobre si mesmo. De acordo com este prin-
cípio, o som não pode nem se prolongar indefinidamente nem seguir numa va-
riedade dispersa. Como a base formada pelo eu é abstrata, a repetição uniforme
deve se revelar como uma repetição necessariamente abstrata. Éesta abstração
que funda a mensuração do tempo a partir de uma unidade. (GUBERNIKOFF,
1993, p. 30)

Selecionamos esta citação para buscar esclarecer a importância dos gestos de dessubjetivação empreendidos por compositores da primeira metade do século XX. Já podíamos observá-los na exterioridade com que Debussy nomeia seus prelúdios. As referências são sempre exteriores, nunca subjetivas. O mesmo se passa com Stravinsky, que rejeitava qualquer menção a liberdades interpretativas subjetivas.

Messiaen, que partilha com Debussy a observação exteriorizada, vai se voltar para a natureza para desenvolver processos composicionais que misturam temporalidades distintas a partir da observação de seus elementos. Encontramos em sua obra dois grandes gestos em relação à temporalidade musical. O primeiro é o valor acrescentado às figuras evalores rítmicos que desloca toda regularidade, as aumentações e diminuições regulares e irregulares e as figuras rítmicas em palíndromos, espelhadas em torno de eixos de simetria.

O segundo é a extrema liberdade temporal trazida pela observação da natureza, onde toda a regularidade abstrata é submetida à não-linearidade das diferentes temporalidades. Podemos ouvir o canto dos pássaros, e também os abismos, as paisagens, mas nunca a subjetividade sentimental ou oeu do inconsciente. A religiosidade também exerce um papel importante uma vez que, para ele, a presença divina está em toda parte, num panteísmo cristão e franciscano. Em Le Loriot, número dois do primeiro volume 
do Catalogue, podemos observar como funciona esta extrema liberdade, submetida a uma lógica composicional de extrema economia de meios. As diferenças são de andamento, de material harmônico, textura, caráter.

\section{LE LORIOT \\ (oriolus oriolus)}
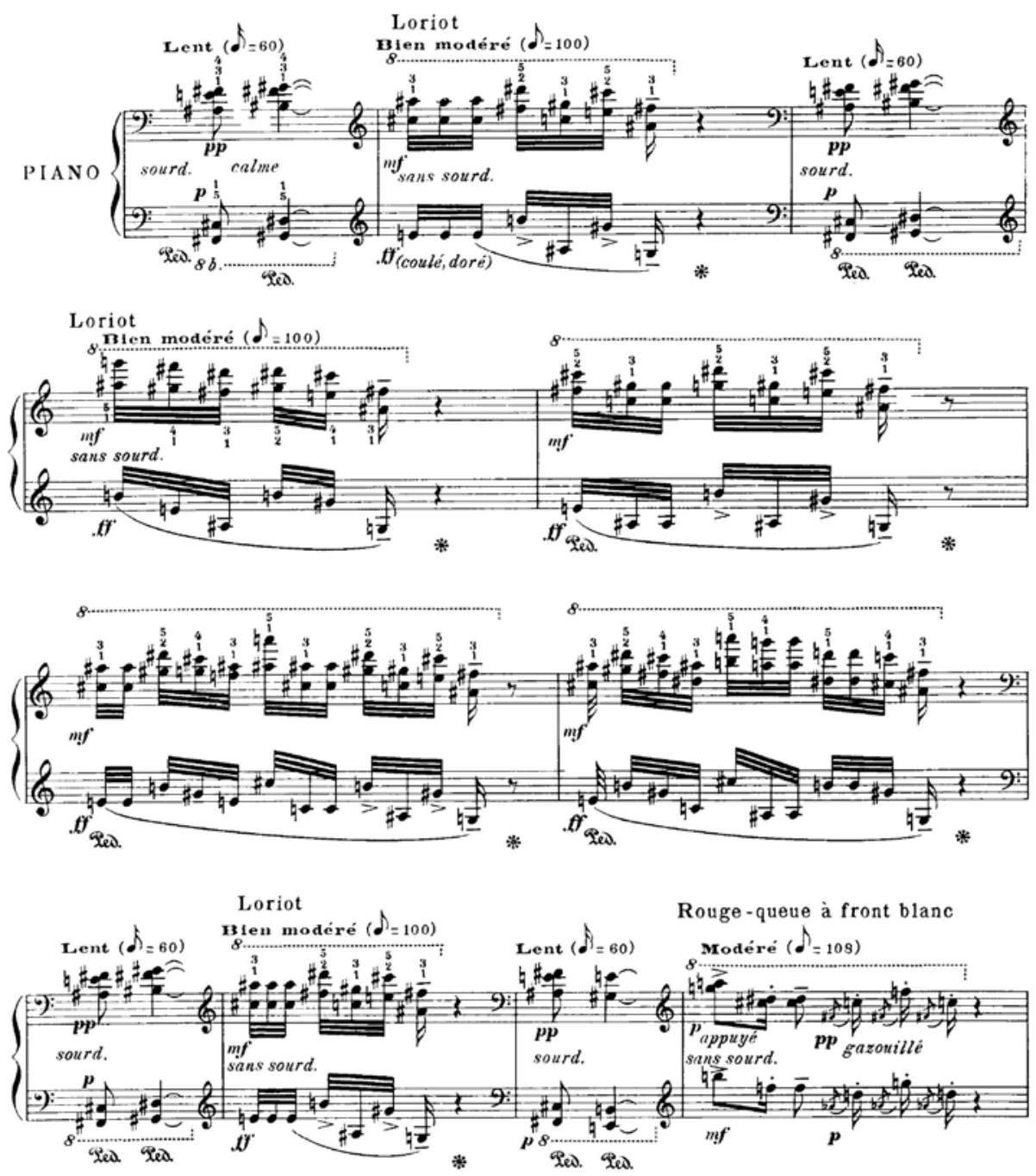

Fig. 8. Olivier Messiaen. Catalogue d'Oiseaux, " Le Loriot ॥. Paris, Leduc, 1944.

Antes do pássaro, o amanhecer no compasso 1, com suas cores que emergem do fundo em pianíssimo. Em seguida, o despertar do pássaro, com seu canto claro e nítido. As harmonias escuras do amanhecer, (do\# menor), na velocidade de 60 por semicolcheia, lent, em contraste com o pássaro a 100 por colcheia, bien moderé. Aos poucos, o pássaro ganha mais vida, com extensões mais longas de tempo não medido que só pode ser entendido pelas configurações, até que novos pássaros surjam, cada um em sua velocidade própria, onde a barra de compasso serve apenas para separare delimitar as velocidades: lent, bien moderé, moderé, très vif. Cada seção será delimitada por uma 
espécie de pássaro, por uma velocidade e por um contorno expressivo em que notas fixas se permutam para formar os perfis melódicos. Certamente a pura observação da natureza não teria levado a uma escrita composicional tão complexa, tanto do ponto de vista harmônico quanto formal. Ela se acompanhou de uma observação atenta à partitura, sobre a qual se debruçou atentamente, como nos comprovam seus escritos póstumos e o depoimento de seus alunos, e onde se encontram seções delimitadas por velocidades associadas a gestos e texturas.

Podemos dizer que Arnold Schoenberg, o libertador da harmonia tonal, não acompanhou a extrema liberdade rítmico corporal, e por este motivo foi duramente criticado por Pierre Boulez no notório artigo "Schoenberg está morto", publicado no ano seguinte ao falecimento efetivo do compositor ${ }^{13}$. Entretanto, se observarmos atentamente suas partituras do período expressionista, como Klavierstucke op. 11 , veremos que a regularidade fraseológica é rompida pela força interior da expressão musical que se encontra nas configurações rítmicas e nas reiteradas mudanças de andamento. Nestas obras, a quebra da regularidade métrica é produzida por uma distorção da representação clássica. Na figura 9, vemos uma exposição de onze compassos (número primo). A primeira frase, acéfala, tem 3 compassos. A segunda frase, também acéfala, repete 3 vezes um membro de frase que vai se expandindo atéalcançar quatro compassos (as duas somam 7 compassos, número predileto de Schoenberg). A primeira frase volta com pequenas variações, construindo um aba deformado em relação à regularidade normativa. Podemos identificar estas distorções com o momento expressionista da arte, que torce corpos, objetos e natureza. Aqui, é a regularidade que persiste de maneira distorcida.

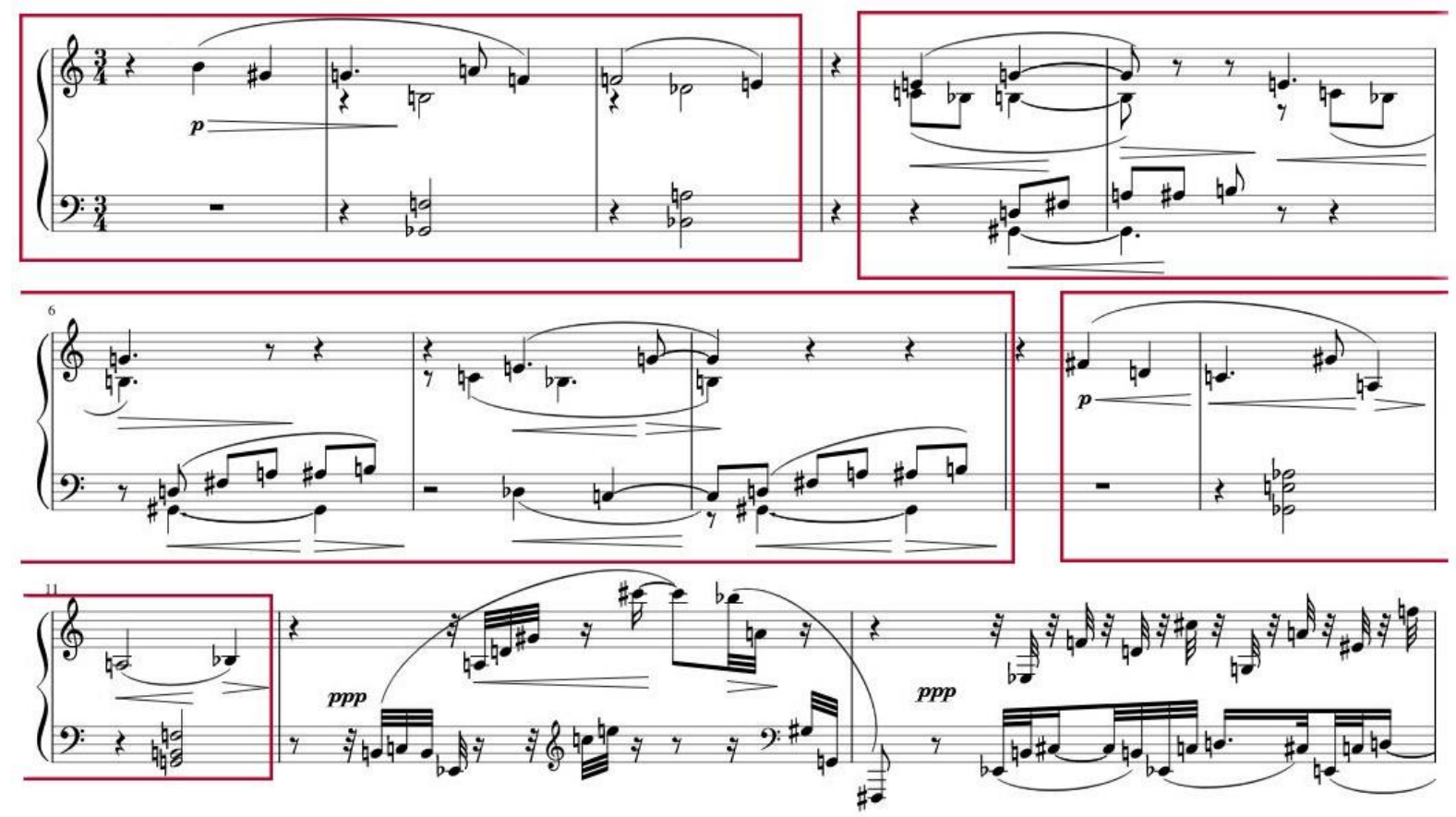

Fig.9. Arnold Schoenberg. Drei Klavierstücke, Op.11, n¹.

13 BOULEZ, Pierre. « Schoenberg est mort”. In: The Score, n 6, fev 1952, p. 18-22; republicado em BoULEZ, Pierre. Relevés d'apprenti. Paris: Seuil, 1966, p. 265-274. 
Anton Webern levará o impulso expressionista da distorção da figura às últimas consequências, por meio da penetração do silêncio. Nas Sechs Bagatellen, Op. 9, podemos verificar não apenas o que Henri Pousseur identificou como pontilhismo, que viria a ser um traço estilístico de várias gerações de compositores pós-tonais, ou o cromatismo total, mas um desejo expresso de separar configurações que se distribuem por um espaço-tempo homogêneo, criando gestos sem identificação da fonte, quase acusmáticos, penetrados pelo silêncio. É curioso que Boulez tenha feito uma leitura estrutural dos silêncios nas obras de Anton Webern, uma vez que estes silêncios invadem o campo do sonoro, trazendo à superfície o sem fundo da temporalidade pura. Para Boulez, as pausas e os silêncios equivalem a um valor negativo. Privilegiamos aqui uma leitura em que os silêncios são orgânicos, expressando um vitalismo não pulsativo, eventos configurados por forças de contração e extensão, condensação e esgarçamento, densidades e volumes multiformes levando à emergência de uma temporalidade pura.

Este conceito é semelhante ao conceito de tempo puro que encontramos no pensamento de Henry Bergson, em que o tempo da memória, que pode ser tempo passado no presente, levaria a um tempo anterior a toda memória. Numa carta recolhida por seu biógrafo Hans Moldenhauer, Anton Webern manifestou seus impasses estéticos na época em que compunha as Bagatelas:

Primeiro uma palavra: anjo. Daí vem o clima da peça. Os anjos no céu. $\mathrm{O}$ incompreensível após amorte [.. ] entretanto eu não gostaria de separar o "aqui" do "além". Não mesmo. Na verdade, de que servem todos os anjos se a minha peça não for boa? (MOLDENHAUER, 1979, p. 192)

Na primeira das Seis Bagatelas, Opus 9, podemos ver as forças de configuração rítmica que se projetam em grupos retorcidos, e que são entrecortados por eventos mais sonoros do que musicais: pizzicatos, na madeira, rulos percussivos. Estas forças criam blocos sonoros atravessados pelo silêncio. 
Sechs Bagatellen für Streichquartett $\mathbf{3}$
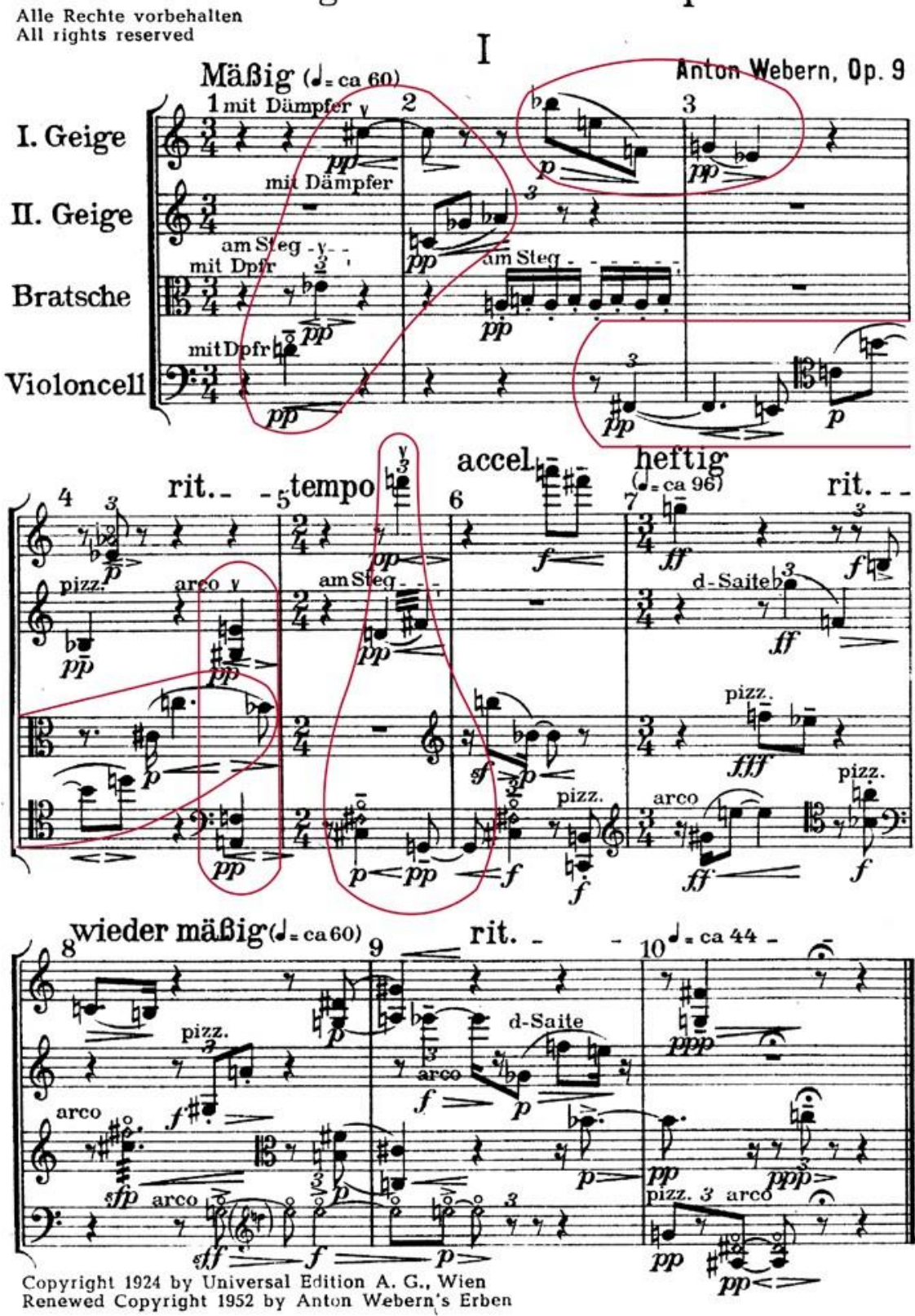

Fig. 10. Gestos direcionais em Anton Webern, Sechs Bagatellen, Op. 9.

Encontramos nos pensamentos de Henry Bergson, nas leituras realizadas por Gilles Deleuze, um passado puro que nunca foi presente, e em Anton Webern, confluências na direção de uma reflexão sobre diferentes temporalidades, ambas atravessadas pelo sem tempo. As forças de organização do pensamento e do material sonoro vão encontrar ecos em outras formas de temporalidade pura, apenas com reflexos menos individuais. Em Webern, o estudo da musicologia foi determinante para a construção de temporalidades sobrepostas e simultâneas, uma vez que em sua tese se debruçou sobre os motetos polifônicos do compositor franco-flamengo Heinrich Isaac. Na notação rítmica, as minúcias duracionais de cada figura mimetizam a instabilidade das execu- 
ções instrumentais do início do século XX, com seus desencontros, acelerações e desacelerações, provocando distorções nas regularidades. Sejam quais forem os motivos, Webern estabelece, pela primeira vez, com seus trinados, pizzicatos e sons harmônicos, toda uma transfiguração sonora atravessada pelo tempo e pelo silêncio. Em suas partituras, aparentemente todos os tempos estão ocupados, a não ser em pequenas respirações e suspiros. Mas os silêncios, representados pelas pausas, atravessam todo o campo sonoro, criando transparências e véus por onde vislumbramos o silêncio e a eternidade.

*

Nos fundamentos da reflexão filosófica sobre o tempo, a música comparece como elemento essencial à sua inteligibilidade. A música é, na linhagem de pensamento pitagórico-platônica, a expressão da medida e da proporção. Ciência do bem medir, do bem proporcionar para Santo Agostinho - musica est scientia bene modulandi - a música faz espelharem-se os ritmos do mundo e os ritmos do canto. Jean de Garlande, nos primórdios da contagem regular do tempo musical, o confirmará, afirmando que a música é a ciência do número em relação com os sons. A partir da rítmica do canto e da memória da métrica clássica na cultura medieval, constituiu-se, a partir de fins do século XII, um tempo musical racionalmente organizado, controlável, manipulável. Ele se ofereceu como terreno fértil para explorações criativas baseadas essencialmente sobre as durações, num crescendo de complexidade extraordinário, até fins do séculoXV. Dos experimentos com o tempo musical deste período permanecerá sobretudo, depois de expurgado o interesse pela matemática sonora, pela intelecção idealista e criativa do tempo musical, um repertório de figuras aptas a mimetizar as inflexões e a semântica dos textos, e uma métrica capaz de oferecer às expectativas humanistas de coesão entre texto e música uma quadratura ajustável à estrutura fraseológica do texto. Num processo que acompanha a constituição e consolidação da tonalidade harmônica, a construção musical se cola ao devir textual novamente, tal como o fazia em sua fase pré-mensural, mas agora de uma forma nova: projetada para frente num passo-a-passo métrico, parametrizado, inexoravelmentedirecionadoàtônica, ponto de fuga da composição. Emoutras palavras, poderíamos dizer que as construções rítmicas da ars antiqua da ars nova, e em certa medida as explorações proporcionais do século XV, se organizavam como uma economia do tempo presente, da agoridade. Cristalizações de uma arquitetura sonoro-temporal, elas demandam a contemplação de uma forma ideal que não é necessariamente apreendida no tempo da escuta, no seu desenrolar, mas sim numa visão intelectual, descolada deste tempo, para além dele. Elas serão seguidas pelas construções que acompanham a emergência da música tonal, que gera e gere expectativas auditivas, ou seja, que se organiza como uma economia do tempo futuro. Assim, não é um acaso que no início do século XX, quando parecem se esgotar as possibilidades desta gestão de expectativas administrada pela conjunção entre tonalidade e métrica, a questão da rítmica se apresente novamente em sua potência de criação de configurações. Não que a rítmica não estivesse presente antes, na lógica ternária da métrica, da harmonia e do ritmo. Mas, liberta-se e refulge no acento e no gesto impulsionador. 


\section{Referências}

AGOSTINHO, Santo. De Musica. Paris: Éditions du Sandre, 2009.

BARRAQUÉ, Jean. Debussy. Paris: Seuil, 1994 [1 962].

BEDA. De arte metrica et de schematibus et tropis [c. 710]. In: COPELAND, Rita; SLUITER, Ineke. Medieval Grammar and Rhetoric: Language Arts and Literary Theory, $A D 300$-1475. Oxford: Oxford Scholarship Online, 2015.

COCLICO, Adrien Petit. Compendium musices, 1552. Disponível em: <https://archive. org/details/imslp-musices-coclico-adrianus-petit/page/n43/mode/2up>. Consultado em maio de 2020.

DELEUZE, Gilles. O Bergsonismo. Rio de Janeiro: 34 Letras, 1999.

EMMANUEL, Maurice. Histoire de la langue musicale. Paris: H. Laurens, 1911.

GUBERNIKOFF, Carole. Música e Representação, das durações aos tempos. Tese de doutorado. Rio de Janeiro, UFRJ, 1993.

MOLDENHAUER, Hans. Anton Von Webern: a Chronicle of His Life and Work. New York: Knopf, 1979.

MURRAY, Alexander. Reason and Society in the Middle Ages. Oxford: Clarendon Press, 2002 [1978].

PLATÃO. Timeu-Critias. Coimbra: CECH, 2011.

SCHMITT, Jean-Claude. Les rythmes au Moyen-Âge. S/I: Gallimard, 2016.

ZARLINO, Gioseffo. Istitutioni Harmoniche, Veneza, 1558. Disponível em: < https:// gallica.bnf.fr/ark:/12148/bpt6k58227h/f2.image>. Consultado em maio de 2020. 